\title{
Chapter 26:
}

\section{Water security and environmental justice in Nigeria and South Africa: achievable concord or discordant alliance?}

\section{Irekpitan Okukpon}

\section{Introduction}

As the world seeks responses to converging risks from inequality and environmental change, attention is placed on the role of improved governance for sustainable development. The way in which ecosystems and natural resources are currently governed often results in deprivation, marginalisation and structural inequality. ${ }^{1}$ In many contexts, "environmental degradation generates further poverty by the exhaustion of natural resources and creates prejudice to the exercise of basic rights". ${ }^{2}$ Poor and vulnerable communities suffer from various forms of environmental injustice, often unable to fight back and reverse trends, which keep them mired in a state of exclusion. ${ }^{3}$ Without a paradigm shift in how natural resources and the environment are valued and governed, inequality will deepen and post-2015 developmental goals will be threatened, if not reversed. ${ }^{4}$

The concept of environmental justice has arisen, in this context, as a mechanism of accountability and legal transformations aimed at curbing abuses of power that result in the poor and vulnerable suffering disproportionate impacts of pollution and lacking equal opportunity to access and benefit from natural resources. ${ }^{5}$ Environmental justice emerged as a self-conscious movement in the $1980 \mathrm{~s},{ }^{6}$ originally focused on the inequity of the distribution of toxics and hazardous waste in the United States of America, but has now moved far beyond this. ${ }^{7}$ A major focus of the environmental justice scholarship has always been a move beyond the simple description and documentation of inequity into a thorough analysis of the underlying reasons for that injustice. ${ }^{8}$ It also involved participatory justice, namely speaking for ourselves or a seat at the table; a

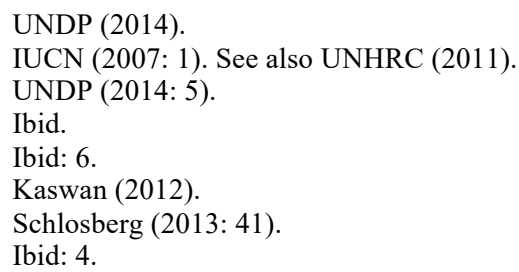


'justice' encompassing not only equity, recognition and participation, but more broadly, the basic needs and functioning of individuals and communities. ${ }^{9}$ In its latest incarnation, environmental justice is also about the material relationship between human disadvantage and vulnerability and the condition of the environment and natural world in which that experience is immersed..$^{10}$ Currently, the environmental justice movement challenges the exclusive nature of environmental decision-making, working to ensure that the voices of those most affected get attention in transparent environmental decision-making processes. ${ }^{11}$

The inequities of water security in developing countries have become a global environmental justice issue. Water security has been described as: ${ }^{12}$

adequate protection from water related disasters and diseases and access to sufficient quantity and quality of water at affordable cost to meet the basic food, energy and other needs essential for leading a healthy and productive life without compromising the sustainability of vital ecosystems.

Accordingly, water embodies the link between human needs and sustainability of resources that is very present in environmental justice debates. ${ }^{13}$ Decision-making regarding accessibility of water and its management is deeply political and contested, ${ }^{14}$ with the water domain being dominated by top-down and closed decision-making processes, where the concerns of the marginalised and disenfranchised citizens have not been taken seriously. ${ }^{15}$

This chapter discusses water security from an environmental justice perspective, highlighting inequities that arise from water management in general. It emphasises the need to apply an adaptive governance approach to water security issues, exploring the extent to which such an approach has been segued into developing countries like South Africa and Nigeria, which are both plagued with water inequities. The chapter further discusses South Africa in comparison with Nigeria because of the inequities of apartheid experienced in the former and the continued evolution of legislation and environmental justice to address any form of inequities, particularly, in relation to water and other basic human needs. Hence, the chapter examines existing legislation on water in both jurisdictions with a view to proffering a reconstructive theory of the concept of water security and what it should entail in a continuously changing world. The chapter further reflects on the importance of the right to water in both jurisdictions and how this right accords each jurisdiction the momentum and tools to entrench the concepts of environmental justice and adaptive governance in achieving water security.

9 Ibid: 5 .

10 Ibid: 16.

11 Chiro (1996); and Vanderwarker (2012).

12 Pachova et al. (2008).

13 Agyeman et al. (2002); and Allouche et al. (2014).

14 Zeitoun (2013).

15 Mehta et al. (2007). 
The global recognition of the human right to water is fundamental to the concept of water security. The globally endorsed human right to water has been the result of intense global struggles for decades until November 2002, when the United Nations Committee on Economic, Social and Cultural Rights adopted a General Comment on the Right to Water. ${ }^{16}$ It provided an authoritative, but not legally binding interpretation of the right to water under the International Covenant on Economic and Social Rights. ${ }^{17}$ General Comment 15 states: ${ }^{18}$

The human right to water is indispensable for leading a life in human dignity. It is a prerequisite for the realization of other human rights.

The central hypothesis behind General Comment 15 is summarised in the second paragraph: ${ }^{19}$

The human right to water entitles everyone to sufficient, safe, acceptable, physically accessible and affordable water for personal and domestic uses. An adequate amount of safe water is necessary to prevent death from dehydration, to reduce the risk of water-related disease and to provide for consumption, cooking, personal and domestic hygienic requirements.

Through much lobbying and struggle, access to clean water and sanitation was finally recognised by the General Assembly of the United Nations as a human right in July $2010 .{ }^{20}$ Later that year, the UN Human Rights Council affirmed by consensus that the right to water and sanitation is derived from the right to an adequate standard of living, which is contained in several international human rights treaties and that it is both justiciable and enforceable. ${ }^{21}$ The official recognition of the right to water was a great victory for the global water justice movement and has been used as a powerful mobilising tool for water struggles around the world. ${ }^{22}$ In global climate circles, one hears the expression 'water security' used with ever-increasing frequency together with declarations about the urgency to increase water security in these times of unprecedented global change and future uncertainty. ${ }^{23}$ There is no agreement among experts on the terminology and some show little concern over its precise meaning, but it is generally conceived as the interaction between physical stress on water resources, the risk of

16 OHCR General Comment No. 15: The Right to Water (Arts 11 and 12 of the Covenant) Adopted at the Twenty-ninth Session of the Committee on Economic, Social and Cultural Rights, on 20 January 2003, Document E/C.12/2002/11 (Geneva: CESCR).

17 Langford (2005: 275).

18 OHCR General Comment No. 15.

19 OHCR General Comment No. 15: para. 2; Hardberger (2005-2006: 348).

20 Mehta et al. (2007: 160).

21 United Nations News (2010).

22 Mehta et al. (2007: 160).

23 Foster \& MacDonald (2014: 1489). 
water-related hazards and the coping capacity in water management of the society concerned. $^{24}$

Traditionally, water security had two meanings which apply both to the rights of an individual or to the claims of a state on behalf of its citizens. The first meaning is a firm water right, which can be judicially or diplomatically enforced against those who interfere with it. ${ }^{25}$ Domestic water law is a structure to channel and minimise conflict and competition because the object of all water law is to allow the acquisition of firm, quasi-exclusive rights to the use of water ${ }^{26}$ It does this by minimising but not eliminating the risks inherent in the use of water. ${ }^{27}$ The second traditional meaning of security is a physically dependable supply which can be tied to a legal allocation or it can be simply based on capture and a low risk that any other party can interfere with the capture. In both arid and humid areas, water rights are provided by a right backed up by carry-over storage, dams and reservoirs. ${ }^{28}$ Thus, as a result of increasing uncertainty about future supplies, the concept of water security today is being expanded beyond these traditional definitions to include the guarantee of sufficient water for a nation's sustainable food production. ${ }^{29}$ The concept has received increased attention over the past decade in both policy and academic communities. ${ }^{30}$ The assumption is that unless sufficient water exists for this and related health purposes, the lack of water will become a source of social insecurity or violence. ${ }^{31}$

Multiple definitions of the concept of water security exist, promoted by a variety of governments and international organisations. Domestic water management agendas in the past decade have embraced water security, leading some to characterise the concept as "a key objective of a range of governmental and non-governmental agencies across the spectrum of governance levels". ${ }^{32}$

Defining water security from a global perspective

The water security paradigm re-orients the goals of natural resource and environmental law and policy to achieve "an acceptable quantity and quality of water" with acceptable costs and risks. ${ }^{33}$ Water lies at the heart of human conflict and cooperation. Water

24 Ibid.

25 Tarlock (2008: 715).

26 This characterisation of a water right was adopted by the New Mexico Supreme Court in Walker v. United States, 162 P.3d 882, 888 (N.M. 2007).

27 Tarlock (2008: 715).

28 Ibid.

29 Postel (1999).

30 Cook \& Bakker (2016: 19).

31 Tarlock (2008: 715).

32 Cook \& Bakker (2016: 19).

33 Grey \& Sadoff (2007: 547-548); and Tarlock \& Wouters (2009: 53). 
security is the most integrated and accessible paradigm needed to move natural resource law and policy forward. ${ }^{34}$ Interest in water security has expanded since the United Nations (UN) Ministerial Declaration of The Hague on Water Security in the $21^{\text {st }}$ Century was issued at the World Water Forum in $2000 .{ }^{35}$ The Ministerial Declaration led to wide use of the term in global policy development and science agendas over the past 15 years. ${ }^{36}$ In response, definitions have proliferated, generating both convergence and confusion about the concept and options for measuring and managing water security. ${ }^{37}$ The Ministerial Declaration describes the water security challenge as: $^{38}$

ensuring that... ecosystems are protected and improved; that sustainable development and political stability are promoted, that every person has access to enough safe water at an affordable cost to lead a healthy and productive life, and the vulnerable are protected from the risks of waterrelated hazard.

In multilateral policy circles, the most widely quoted definition appears to be that of the Global Water Partnership (GWP), which defines water security as "a common goal” where "...every person has access to enough safe water at affordable cost to lead a clean, healthy and productive life, while ensuring that the environment is protected and enhanced". 39

The water security and growth session at the fourth World Water Forum in 2006 was an important milestone in recent science and policy agendas. Grey and Sadoff ${ }^{40}$ examined the relationship between water security and human development, yielding a definition of water security based on water's productive uses and potential destructive impacts. They describe water security as the "availability of an acceptable quantity and quality of water for health, livelihoods, ecosystems and production, coupled with an acceptable level of water-related risks to people, environments and economies". ${ }^{41}$

Although this definition is more encompassing because it embraces both a riskbased perspective and addresses the role of water as both source of services and a source of threat, what is 'acceptable' is subject to different interpretations by different groups. ${ }^{42}$ This definition raises a number of key challenges: what does acceptable mean for health, livelihoods, environment and production and how can this be determined? How should one determine an 'acceptable quantity' in different contexts? How should

34 Larson (2017: 164).

35 United Nations Ministerial Declaration of The Hague on Water Security in the 21st Century (2000).

36 Garrick \& Hall (2014: 613).

37 Cook \& Bakker (2012); Garrick \& Hall (2014: 614); Obani \& Gupta (2016: 201).

38 United Nations Ministerial Declaration of The Hague on Water Security in the 21 st Century (2000: 1).

39 Global Water Partnership (2000).

40 Grey \& Sadoff (2007).

41 Ibid.

42 Pahl-Wostl et al. (2013: 676). 
one determine an 'acceptable quality' for different users and different uses? How should one assess 'water-related risks' acceptable 'to people, environments and economies' in the face of multi-decadal changes in water extremes (floods and droughts) and uncertainties in future climates ${ }^{23}$ These issues are a pointer that enhancing water security is first of all a governance challenge. ${ }^{44}$

Most recently, UN-Water used a dialogue process to define water security based on the multiple interests tied to it. ${ }^{45}$ The resulting working definition describes water security as the: ${ }^{46}$

capacity of a population to safeguard sustainable access to adequate quantities of and acceptable quality water for sustaining livelihoods, human well-being, and socio-economic development, for ensuring protection against water-borne pollution and water-related disasters, and for preserving ecosystems in a climate of peace and political stability.

This chapter adopts the following definition of Jun Xia et al. ${ }^{47}$

...water security includes: (a) population-wide security, that is, everyone can obtain secure water for domestic use; (b) economic security, namely water resources can satisfy the normal requirements of economic development; (c) ecological security, namely water resources can meet the lowest water demands of ecosystems without causing damage.

Similarly, the United Nations Development Programme (UNDP) views water security as an integral part of the broader conception of human security: ${ }^{48}$

In broad terms, water security is about ensuring that every person has reliable access to enough safe water at an affordable price to lead a healthy, dignified and productive life, while maintaining the ecological systems that provide water and also depend on water. When these conditions are not met, or when access to water is disrupted, people face acute human security risks transmitted through poor health and the disruption of livelihoods.

These definitions reflect in part, the influence of different conceptions of security and the implications of these differences for water management. ${ }^{49}$ Thus, four dimensions of water security were noted in the debate of Cook and Bakker. ${ }^{50}$ water stress and availability; vulnerability to hazards, human development needs, and sustainability. Wouters et al. ${ }^{51}$ have also identified three core constituent elements of water security: availability (controlled supply of quality and safe water); access (enforceable rights to water for a range of stakeholders); addressing conflicts of use (where competing uses occur, a mechanism to avoid and/or address disputes is needed. Flowing from this,

43 Ibid: 676 .

44 Ibid: 677.

45 Garrick \& Hall (2014: 614).

46 UN-Water (2013).

47 Xia et al. (2007).

48 UNDP (2006).

.49 Allouche et al. (2011: 160).

50 The first three can be understood through a risk lens. Hall \& Borgomeo (2013: 371); and Cook \& Bakker (2012).

51 Wouters et al. (2009). 
water security appears to be a societal issue, and, thus, a political concern, ${ }^{52}$ which has become increasingly important both at the national and international levels. Through the concept of water security, states seek to respond to the increasing threats to their water supply and quality and also to the potentially increasing conflicts and tensions arising between states. ${ }^{53}$

It therefore appears that understandings of the different requirements for achieving water security will vary between different regions and different countries, especially, between 'mature' and developing water management regimes. Any global water security framework must cater for different regions having different water security issues: for example, regional flood control, reducing drought disaster, water pollution control, and ecosystem conservation. ${ }^{54}$ Although there are differing demands for understandings of water security in different regions, different countries at different levels of development, regional water security strategies could be developed under the framework of global water security. This global framework could emphasise the most important water security issues in each region, as the ones mentioned above, by linkage of hydrological cycle, while maintaining the goal of global water security. ${ }^{55}$ The important thing is to recognise the underlying systemic nature of water security, so that the impacts or consequences of water security activities are considered in the light of human welfare and environmental responsibility, namely sustainable development. ${ }^{56}$ This chapter, therefore, argues that the key to achieving an effective water security framework in developing jurisdictions is through the concept of adaptive governance. An exposition of this encompassing concept geared towards consolidating legal, social, economic and political processes in relation to natural resources like water is carried out below.

\subsection{Using adaptive governance to achieve water security in developing countries}

The introductory part of this chapter highlighted the role of environmental justice as one concerned with legal transformations aimed at ensuring that the poor do not lack equal opportunity to access and benefit from natural resources such as water. ${ }^{57}$ Beyond mere revisions of strategies and regulations, empowering the poor requires broad systemic changes to laws and institutions that help overcome exclusion of the poor from their right to a healthy environment and support equal opportunity to access and benefit

52 Foster \& MacDonald (2014: 1489).

53 Soyapi \& Honkonen (2017: 2).

54 Allan et al. (2013: 630).

55 Ibid.

56 Ibid.

57 UNDP (2014: 6). 
from natural resources. ${ }^{58}$ Hence, adaptive governance entails the ability to generate long-term sustainable policy solutions to complex and dynamic environmental problems through collaboration among diverse stakeholders. ${ }^{59}$ Governance is viewed as adaptable, flexible and repetitive; it extends from natural systems to human organisations. ${ }^{60}$ Improved governance is seen as a force to regulate social, environmental and economic trade-offs in the process of development, and supporting an enabling environment of institutions that engender 'triple win' solutions for goals of sustainability, inclusion and resilience. ${ }^{61}$ It reacts to change in ecological and human institutions and systems as science continues to evolve. ${ }^{62}$ The concept can ensure flexibility in regulation $^{63}$ on water to ensure accessibility, affordability and availability of the resource to all. Hence, water governance is viewed as "the political, social, economic and administrative systems that are in place, and which directly affect the use, development and management of water resources and water service delivery at different levels of society" ${ }^{64}$

Accordingly, for adaptive governance to be applied to water-related issues in any jurisdiction, such political, social, economic and administrative systems on water must support the adaptive capacity of society, often, with an iterative approach to policymaking, stressing flexibility of the regulatory instruments. ${ }^{65}$ The application of adaptive governance to water governance requires policymakers to act despite uncertainties. ${ }^{66}$ Experimental interventions require resilience, supervisory and accountability mechanisms, and the assurance that adaptive management interventions do not risk unacceptable and irreversible outcomes. ${ }^{67}$ The hope is that the technique of these scientific interventions will permit decision-makers to avoid the paralysis that scientific uncertainty creates by viewing management as an experiment that can progressively reduce scientific uncertainty over time. ${ }^{68}$ Adaptive governance favours impermanent policy interventions and adoption of strict oversight mechanisms to encourage

58 Ibid.

59 Scholz \& Stiftel (2005: 5).

60 Onzivu (2013: 625).

61 'Triple win' solutions in the sustainable development context covers economic, social and environmental 'pillars' to be thought of as synergistic and integrated stands that 'lend' themselves to inter-weaving and linkages. For more information, see $<$ http://www.undp.org/content/dam/undp/library/Cross-Practice $\% 20$ generic\%20theme/Triple-Wins-for-Sustainable-Development-web.pdf $>$ (accessed 14-12-2017).

62 Ruhl (1997: 933); Folke et al. (2005: 441); and Oglethorpe (2002).

63 Onzivu (2013: 625).

64 See <http://watergovernance.org/whatiswatergovernance> (accessed 12-12-2017); and PahlWostl et al. (2013: 677).

65 Honkonen (2017: 3).

66 Onzivu (2013: 626).

67 Armitage et al. (2007: 83); and Gunderson (1999: 7).

68 Tarlock (2008: 728). 
flexibility. ${ }^{69}$ Dietz et al. ${ }^{70}$ propose the first general list of criteria necessary for adaptive governance: inclusive dialogue between resource users - analytic deliberation - (complex); redundant layered institutions (nesting); mixed institutional types (such as market and state-based); and institutional designs that facilitate experimentation, learning and change. Thus, policy-making in adaptive governance is an iterative process of review and revision, requiring no rest for actors in a complex adaptive system. ${ }^{71}$ The smooth functioning of this iterative process depends critically on the progressive development of mechanisms for the regular monitoring of specificity of processes and outcomes of policy interventions. Outcomes of monitoring processes routinely feed back into the policy process to re-assess policy goals, assumptions and objectives themselves. $^{72}$ Such self-conscious monitoring and feedback mechanisms facilitate learning, fine-tune policy instruments, highlight knowledge gaps, reveal the shortcomings of problem definition and knowledge, and create a culture of openness and experimentation in the conduct of policy. ${ }^{73}$

The process of adaptive governance to water systems also incorporates the intertwining of environmental justice in order to achieve water security in developing jurisdictions. If disputes over water management or the inequalities associated with water arise, it is expected that the network of systems in place (social, economic, political, legal and administrative) ensures that access to justice is available to stakeholders and that the public administration of water remains within legal bounds. ${ }^{74}$ These stakeholders should, therefore, be able to enforce their right to public participation and to challenge acts, administrative decisions and omissions in the implementation of water plans and programmes of measures. ${ }^{75}$

Environmental justice movements often challenge dominant systems and global understandings of the environment-development balance, and systems of rights and justice. This is particularly the case in traditional and indigenous communities where cultures and ways of life are uniquely tied to the environment, and which have faced especially harsh forms of alienation and environmental dispossession for centuries. ${ }^{76}$ Standing as the poorest and most socially excluded communities in the world, indigenous and tribal communities also host much of the planet's remaining reserves of natural resources ${ }^{77}$ like water.

\footnotetext{
69 Hornstein (2005: 929-933).

70 Dietz et al. (2003).

71 Ruhl (2009: 903); and Onzivu (2013: 626).

72 Cooney \& Lang (2007).

73 Ibid. See also Onzivu (2013: 626).

74 Keesen \& van Rijswick (2012: 43).

75 Ibid.

76 UNDP (2014: 10).

77 Ibid.
} 
South Africa is a water-stressed country with a high proportion of arid land. More than $90 \%$ of South Africa is categorised as arid, semi-arid or sub-humid. ${ }^{78}$ South Africa's economy is highly dependent on natural resource use, even though the economy has latterly become diversified. ${ }^{79}$ There are strong links between agricultural land uses and high levels of water use in South Africa ${ }^{80} 86 \%$ of the land area in South Africa is used for agriculture. ${ }^{81}$ While large parts of the population is heavily dependent on agriculture, much of the country is marginal in terms of dryland agriculture. ${ }^{82}$ Consequently, water for irrigation purposes accounts for a major proportion of water consumption. In this manner, water is regarded as both an environmental 'limit' and a key component for economic prosperity. ${ }^{83}$ The agricultural sector, while maintaining self-sufficiency in most basic food items, has a 'dual structure'. It has a commercial component but has many more subsistence level farmers. ${ }^{84}$ The dual structure is marked by differential access to, and use of, water resources.

As a legacy of the apartheid regime, many black South Africans are concentrated in the rural areas, often living below the international poverty line, and with many having only limited access to water. ${ }^{85}$ The demise of apartheid and the election of the first non-racial and democratic government in South Africa in 1994 remains a major landmark for political and socio-economic development in the country. ${ }^{86}$ Since then, public policy reform discourses have gained more visibility in various sectors of the economy (water sector included). Inequality of access to water resources marked South Africa's history profoundly. ${ }^{87}$

The water law framework was overlain by the apartheid system characterised by a disparity of access to water that operated along racial lines with significant differences in water availability for racial groups in urban and rural areas. ${ }^{88}$ The system of riparian rights, especially in rural regions, tended to favour an inequitable allocation of water as the right to water was tied to landownership. Particularly in the more productive agricultural regions, there were major inequalities as landownership was disproportionately skewed towards the white minority population. ${ }^{89}$ Non-land holders who

78 See $<$ http://www.gcis.gov.za/docs/publications/yearbook.htm> (accessed 18-12-2017).

79 Kasrils (2003: 2).

80 Godden (2005: 185).

81 Willis et al. (2000: 189).

82 Ibid; see also <http://www.gcis.gov.za/docs/publications/yearbook.htm> (accessed 4-12-2017).

83 Peart \& Govender (2001: 51).

84 See $<$ http://www.gcis.gov.za/docs/publications/yearbook.htm> (accessed 4-12-2017).

85 Stein (2000: 285).

86 Chikozho et al. (2017: 270).

87 Ibid.

88 Apartheid legislation distorted access to natural resources, denying the majority of South Africans the use of land, water, fisheries, minerals, wildlife and clean air. See DWAF (1997: 28). 
required water had to make an application to the Water Court. Any access to water so granted was premised on the use not interfering with the existing allocations to riparian owners. The other option was to become a landowner - a status from which many black and coloured South Africans were precluded. ${ }^{90}$ The Water Act 54 of 1956 addressed some water allocation problems as it allowed for Government Water Control Areas in which, in certain circumstances, the Minister could override riparian allocations. Nonetheless, the focus remained on water supply and the 1956 Act failed to respond effectively to issues of environmental degradation, equity of distribution or the downstream effect of water allocations. ${ }^{91}$ The apartheid lawmaker harnessed the law, and the water in the interests of the mostly white dominant class and groups who had privileged access to land and economic power..$^{92}$ Thus, the resulting body of laws and policies and the varied forms of infrastructure that were developed to harness water for multiple social practices over time constituted a complex political ecological terrain that was difficult to redress. ${ }^{93}$

The current vision for water governance in South Africa is, therefore, a product of radical changes in the national socio-economic and political environment. ${ }^{94}$ Redistribution of water rights to redress the results of past discrimination became an explicit purpose of post-apartheid water governance, policy and the legislative regime. ${ }^{95}$ Desired reforms in the water sector were translated into policy documents (a White Paper on National Water Policy 1997) and legislation (the Water Services Act 1997 and the National Water Act 1998). These legislations were geared towards the promotion of equity, sustainability, representativeness and efficiency through decentralisation of water management, new local and regional institutions, water users' registration and licensing and the emergence of a water rights market. ${ }^{96}$ Therefore, the new water policy and law represented a fundamental legal reform in the country as it shifted the focus of formal water control from riparian water title holders, largely consisting of the white minority, to the new government as the custodian of the nation's water resources. Government is now the manager of the nation's limited water resources and not an administrator of a system of rights as in the past. ${ }^{97}$ Towards this end, the effectiveness of these water legislations are analysed below to determine the extent to which it facilitates water security in South Africa.

90 Ibid.

91 Perkins (2003: 148).

92 MacKay et al. (2003: 29); Schreiner et al. (2004: 178); Pienaar \& Van der Schyff (2007); and Woodhouse (2008).

93 Willis et al. (2000: 189).

94 Tewari (2009: 710).

95 MacKay et al. (2003: 29); and Gowlland-Gualtieri (2007).

96 Backeberg (2005: 123); and Chikozho et al. (2017: 270-271).

97 Chikozho et al. (2017: 271). 


\subsection{Water sector reforms in South Africa and water security paradigms}

The Constitution of the Republic of South Africa ${ }^{98}$ ushered in two central provisions that arguably form the backbone of water law in the country. ${ }^{99}$ It contains a Bill of Rights (Chapter 2) intended to ensure the rights of individuals to a clean environment and safe water. ${ }^{100}$ The first provision (Section 24) gives individuals a right to a safe environment that is not harmful to his/her health and well-being and to have the environment protected through reasonable legislative and other measures that prevent pollution, ecological degradation and secure ecological sustainable development. The second provision (Section 27) provides for access to health care services and sufficient food, water and social security. The right to water is provided in Section 27(1)(b): "everyone has the right to have access to sufficient food and water". The Constitution also provides that "the state must take reasonable legislative and other measures within its available resources, to achieve the progressive realisation of each of these rights". ${ }^{101}$ These rights refer to the rights contained in Chapter 2 of the Bill of Rights, including the right to water.

The 1997 White Paper on Water Policy sets out fundamental principles for water law in South Africa. It provides that: ${ }^{102}$

[t]he quantity, quality and reliability of water required to maintain the ecological functions on which humans depend shall be reserved so that the human use of water does not individually or cumulatively compromise the long term sustainability of aquatic and associated ecosystems.

The White Paper also introduced the necessity of a Reserve: ${ }^{103}$

after providing for the basic needs of citizens, the only other water that is provided as a right is the Environmental Reserve - to protect the ecosystems that underpin our water resources, now and into the future.

Additionally, the White Paper recognises certain principles including: (a) water required to meet basic human needs and for the environment shall be identified as the Reserve and shall enjoy priority of use by right. Other uses of water shall be subject to authorisation; ${ }^{104}$ (b) national government has a duty to assess the needs of the Environmental Reserve and ensure that the amount of quality water is set aside; ${ }^{105}(\mathrm{c})$ where the needs of the environmental reserve cannot be met because of existing developments, there must be provision for active intervention to protect the water resources. ${ }^{106}$

\footnotetext{
98 Act 108 of 1996.

99 Chikozho et al. (2017: 274).

100 Ibid: 270.

101 Section 27(2), 1996 Constitution

102 DWAF (1997: Appendix 1, Principle 7); and Takacs (2016: 80).

103 Takacs (2016: 80).

104 DWAF (1997: Appendix 1, Principle 10).

105 Ibid.

106 Ibid.
} 
It must also be noted that Schedule $4 \mathrm{~A}$ to the Constitution provides for the functional areas of concurrent national and provincial legislative competence, whereas Schedule 4B affords the local governments executive authority with regards to provision of water and sanitation services. In other words, the water cycle is administered by two separate spheres of government, that is, national government, which is responsible for the management of water resources, and local government, which is responsible for water services with national government playing a regulatory and oversight role. ${ }^{107}$

As a means to emphasise the importance of water law reforms via legislation, the National Water Act (NWA) 1998 recognises in its Preamble that: ${ }^{108}$

water is a scarce and unevenly distributed resource which occurs in many different forms... [and] that while water is a natural resource that belongs to all people, the discriminatory laws and practices of the past have prevented equal access to water, and use of water resources....

Too often in South Africa, water managers appear to frame the problem of water scarcity/unavailability of water as people not paying enough for the water they receive, thus wasting it. ${ }^{109}$ This assertion appears to be reflected in the NWA 1998, which provides that: ${ }^{110}$

water use charges will be used as a means of encouraging reduction in waste, and provision is made for incentives for effective and efficient water use. Non-payment of water use charges will attract penalties, including the possible restriction or suspension of water supply from a water work or of an authorization to use water.

Larson argues that: ${ }^{111}$

a provision right to water framed in a manner opposed to water pricing and cost recovery is not only counter-productive to its presumed end of protecting disadvantaged communities, but also poses risks to ecological sustainability and human health.

This chapter argues that if water security envisages the provision of adequate water to meet basic human needs, particularly those of previously disadvantaged individuals in a particular jurisdiction, charges for water uses should not be discounted but must be at a rate, which is affordable to all, whether rich or poor.

Similarly, the Water Services Act provides that every water services authority has a duty to all consumers or potential consumers in its area of jurisdiction to progressively ensure efficient, affordable, economical and sustainable access to water services, subject to equitable allocation and regulation of access to water services. ${ }^{112}$ The National Water Resource Strategy 2 (NWRS2) of South Africa reiterates that: ${ }^{113}$

107 Chikozho et al. (2017: 274).

108 Paras 1 and 2, Preamble to the National Water Act (NWA), Act No. 36 of 1998.

109 Takacs (2016: 73).

110 Chapter 5.1, NWA 1998.

111 Larson (2013); and Takacs (2016: 73).

112 Section 11(1) and (2), Water Services Act.

113 DWAF (2013: 47). 
the first objective is to ensure that sufficient quantities of raw water are available to provide for the basic water needs of people. In terms of current policy, a quantity of 25 litres per person per day has been incorporated into the Reserve determination. Even though this is the minimum volume, this will be progressively increased where appropriate.

The NWRS2 recommends that “...the management activities required to ensure the provision of sufficient water for the ecological reserve must be paid for by all registered and billable users...". 114

The extent to which the combined provisions of the Constitution, the National Water Act and the NWRS2 translate to the need for availability, accessibility and affordability of water, which is what the concept of water security envisages. This was also subject of determination in a 2008 case, which sought to provide environmental justice for residents of Phiri, a township in Soweto, Johannesburg, South Africa. The aforementioned case and its implications for environmental justice and water security in South Africa is examined below.

4.2 The implications of Mazibuko on environmental justice and water security in South Africa

Phiri is a township in Soweto (the largest of Johannesburg's suburbs with a population that is $98.5 \%$ Black) with many impoverished residents living in overcrowded conditions. ${ }^{115}$ As is the case in many similar communities in South Africa, few households have in-home running water. ${ }^{116}$ Johannesburg Water Ltd, the state-owned company responsible for delivering water to Phiri residents, was charged both with delivering a scarce resource to a growing population and recouping its costs under a 'full cost recovery' model. ${ }^{117}$ Johannesburg Water claimed that whereas Sowetans consumed onethird to one-quarter of all water delivered by the company, only one per cent of their revenue came from there; both because residents did not pay their bills and because antiquated infrastructure led to leaking pipes and other water waste. ${ }^{118}$ To conserve water and recover expenses, the company instituted a plan where citizens who wanted water piped onto their property would have to install a prepaid water meter. However, after twenty-five litres per person of free basic water flowed, if the residents had not paid fees, their water would be turned off with no advance notice. ${ }^{119}$

Five Phiri residents sued the City of Johannesburg, Johannesburg Water and the Ministry of Water Affairs and Forestry. They alleged that the provision of six kilolitres per household per month did not meet constitutional standards in terms of the right to

114 Ibid: 88 .

115 Magaziner (2008: 512-516).

116 Humby \& Grandbois (2010: 526); and Wesson (2011: 394).

117 Daniels (2006: 63).

118 Mazibuko v. City of Johannesburg 2010 (4) SA 1 (CC) 12 (S. Afr.).

119 Ibid: para. 3; and Wesson (2011: 395). 
water, requesting that the amount be doubled. The plaintiffs also alleged that the installation of pre-paid water meters, which would shut off without notice if bills were not paid, was unconstitutional, violating provisions of the rights to dignity (Section 7); equality (Section 9) and water (Section 27 (b)) of the South African Constitution. ${ }^{120}$ The plaintiffs also alleged that the installation of pre-paid metres in black/poorer communities was discriminatory as this was not the norm in predominantly white communities. They also contended that when the metres were installed, Johannesburg Water gave citizens enough time to pay bills before disconnection, unlike in Phiri.

Accordingly, the Constitutional Court held that the obligation of progressive realisation of water rights imposed a duty upon the state to review its policies continually to ensure that the achievement of the right is realised progressively. ${ }^{121}$ In light of the evidence presented, it could not be said that the provision of six kilolitres of free water per household per month was unreasonable, ${ }^{122}$ especially as the applicants failed to establish that the introduction of prepaid water metres was unlawful. ${ }^{123}$ In a move, which is reflective of how adaptive governance should work with regards to effective utilisation and security of water, the Constitutional Court held that when the state is challenged judicially as to its socio-economic policies, the agency in question must explain why the policy is reasonable; and must disclose what it did (including its investigation and research) to formulate the policy, where alternatives were considered and the reasons why the option underlying the policy was selected. The state may then be challenged judicially to account for its decisions and must accordingly demonstrate that the policy selected was reasonable and in due consideration of its obligation to progressively realise the relevant socio-economic right ${ }^{124}$ - in this case, the right to water.

The case has been criticised by various scholars worldwide. Roithmayr ${ }^{125}$ states that the Constitutional Court "found it constitutional to ration access to water based on the ability to pay, even for the country's poorest black residents" and in doing so, the court "took as its implicit baseline of reasonability...apartheid inequalities of race and class...that target the poor". In effect, finding "these inequalities constitutionally permissible, even though cost recovery from the poor serves to reinforce the legacy of apartheid". ${ }^{126}$ She argues further that the court could have ruled that the city should refrain from aggressive cost recovery-targeted towards the country's poorest via prepaid meters. ${ }^{127}$

120 Magaziner (2008: 532); and Takacs (2016: 84).

121 Mazibuko (2008), para. 67.

122 Paras 82-89.

123 Paras 105-157.

124 Paras 161-161.

125 Roithmayr (2010: 324).

126 Ibid.

127 Ibid: 325-326; and Couzens (2015: 1169). 
Bond ${ }^{128}$ argues that the plaintiffs erred in arguing their case with a focus "only upon the consumption needs of low-income residents" and without looking at a wider societal context. He concludes on the need for "as a first step, more coherent critiques of the full range of practices that undermine our ability to perceive and respect water and other aspects of nature as a Commons". ${ }^{129}$

Whilst agreeing with Bond in this regard, this chapter also adopts the position that the existence of a right to water in the South African Constitution already provided the plaintiffs with enough leeway to argue beyond just consumption needs, but the need for water security. Whilst bearing in mind that the 1996 Constitution was adopted years before the concept of water security became popularised, a broader argument geared towards the need for adaptive governance with respect to natural resources like water would perhaps have resulted in the realisation of a more acceptable judgement for the plaintiffs and, therefore, achieve environmental justice for the Phiri residents. Nevertheless, it must also be noted from the Mazibuko case that whilst the notion of environmental justice is justified on the basis of distributional justice and equity, it is sometimes limited to the courts ability to apply it.

Thus, despite the Constitutional Court's reluctance to enforce the right to water more aggressively in Mazibuko, South Africa presented four documents spanning seventeen years in which lawmakers and policymakers have a blueprint for how government can protect the human right to water to ensure its availability for all. ${ }^{130}$ Current South African water laws mentioned above represent a best practice approach that draws upon a range of scientific, technological, social and economic goals, ${ }^{131}$ which is what the process of adaptive governance requires. Unfortunately, years after the National Water Act was implemented and enforced, access to water is still highly stratified along racial lines. ${ }^{132}$ Kemerink, Ahlersa and van der Zwaag argue that "the dynamics of water politics including water law and rights cannot be understood without also scrutinising the power relations, discourses and discursive practices that guide perceptions of water problems and proposed solutions". ${ }^{133}$ Bearing this in mind, it can be argued that the application of adaptive governance to water law reforms in South Africa is effective in the sense that its current law reforms are clearly predicated on explicit distributive justice goals, which define sustainability as a mixture of ecological and human needs. ${ }^{134}$ This predication on distributive justice provides the required platform for progressively achieving water security in South Africa within the next few decades.

128 Bond (2013: 141-143); and Couzens (2015: 1168).

129 Ibid.

130 Takacs (2016: 97).

131 Godden (2005: 202).

132 Kemerink et al. (2011: 585).

133 Ibid: 586.

134 Godden (2005: 202). 
Nigeria is endowed with adequate freshwater resources with a coastline of about $800 \mathrm{~km}$ in the south and also the Lake Chad Basin in the north. It is blessed with large rivers like the Niger, Benue, Kaduna, Anambra, Imo, Gongola, etc., small lakes, streams and ponds in the rural areas. These water resources are sources of livelihood and wealth creation to many families on a daily basis. ${ }^{135}$ Despite Nigeria's apparent potential water abundance, Nigerians are in short supply. ${ }^{136}$ The Nigerian situation mirrors the sub-Saharan African situation where millions still lack access to safe water supply. Considering that Nigeria is the most populous African nation, it also represents a sizable population of people in sub-Saharan Africa without access to water and sanitation. ${ }^{137}$

In a 2017 report, UNICEF notes that drought and conflict are important factors behind water scarcity in parts of Nigeria. ${ }^{138}$ Currently, over 3.6 million people in NorthEast Nigeria where the Boko Haram insurgency is prevalent, do not have access to basic drinking water as the insurgency has resulted in damage to about $75 \%$ of the water and sanitation infrastructure. ${ }^{139}$ In these areas, and in other rural parts of Nigeria, hand pumps fitted on bore wells and solar-powered motorised water systems are the two main drinking water sources. Although it is natural to expect that these sources provide uninterrupted water supply to the people, ${ }^{140}$ this is not the case in Nigeria. While the concept of water security remains a global one, which should be realised by governments at the national level, water security in North-East Nigeria still appears to be an illusion. This chapter focuses on the apparent lack of water security in NorthEast Nigeria, as it serves to emphasise why the Nigerian government needs to apply more adaptive governance tactics towards achieving water security.

In North-East Nigeria, particularly in the Borno, Yobe and Adamawa (north) states, the Boko Haram insurgency has ravaged and displaced many people, while drinking water in internally displaced persons' (IDP) camps appears to be inadequate. The absence of financial resources is cited as a key reason why IDPs lack access to water, ${ }^{141}$ and priority needs in IDP camps include money to fuel generators to pump water. ${ }^{142}$ Other challenges cited include the lack of funds to pay for water from water vendors, the inability to gain access to public water sources and the inability to purchase suitable water containers to store water. ${ }^{143}$ In the Borno state, the main water sources are water

135 Federal Ministry of Water Resources (2011: 7).

136 Ibrahim (2012: 71).

137 Henderson \& Sundaresan (1982); and UNICEF (2014: 14).

138 Punch (2017).

139 Adebowale (2017).

140 UKAID \& UNICEF (2017).

141 ACAPS (2016: 4).

142 Ibid: 8.

143 Ibid: 14 . 
vendors, unprotected wells, rivers and dam water. Unable to pay for water, IDPs often have to beg the host communities for access to wells and boreholes. ${ }^{144}$

If the concept of water security is one that envisages reliable access to, availability and affordability of water, it is evident that North-East Nigeria is a fertile ground for the application of environmental justice. Nevertheless, an examination of water law reforms by the Nigerian government provides an insight into the extent to which existing legislation on water serves to improve water security, particularly but not exclusively in the North-East region of Nigeria.

\subsection{Water law reforms in Nigeria}

The basis for water law reforms in Nigeria stems from the provision of Section 20 of the Constitution of the Federal Republic of Nigeria (the 1999 Constitution). The provision states that "the State shall protect and improve the environment and safeguard the water, air and land...in Nigeria". This particular provision is contained in Chapter II of the Constitution titled 'Fundamental Objectives and Directive Principles of State Policy.' These fundamental objectives consist of ideals towards which a nation is expected to strive, while the directive principles identify policies, which are expected to be pursued in the nations effort to realise national ideals. ${ }^{145}$ This means that while the state has an obligation to safeguard water resources, such obligation is merely aspirational and not justiciable as Section 20 is not housed within the 'Bill of Rights.' Unlike the South African Constitution, which ensures the right to water is contained in its Bill of Rights, the position of Section 20 in the Nigerian Constitution makes it impossible for an individual who does not have the requisite locus standi to approach the courts for the enforcement of his/her rights to water or that measures to ensure water security be put in place by government to ensure progressive realisation of such rights.

Nigeria has legislation on water, including the National Water Policy and the Water Resources Act. Nigeria's National Water Policy 2004 and the National Water Resources Draft Policy 2016 are subject to and consistent with the 1999 Constitution in all matters and require that water resources shall be assessed, developed, apportioned and managed in such a manner as to enable all users to have equitable access, taking into account the sustainability of the resource. ${ }^{146}$ The Water Resources Act 1993 also vests in the federal government the right to use and control all surface and groundwater and all water in any watercourse affecting more than one state. Thus, any person may take water without charge for his domestic purpose or for watering his livestock from any watercourse to which the public has free access. Any person may use water for

Ibid: 15 .

145 Nnamuchi (2008: 1).

146 Paragraph 5.3.3 Nigerian National Water Policy (2004). 
fishing or for navigation, or may use it from an underground water source without charge for domestic purpose, livestock, personal irrigations schemes if he/she has a statutory right of occupancy over such land. ${ }^{147}$

It should be noted that Nigeria's National Water Policy 2004 was based on the philosophy and principles of the Integrated Water Resource Management (IWRM). Interestingly, the revised National Water Resources Draft Policy 2016 takes into account not only the IWRM, but the underlying philosophy that water is key to sustainable socio-economic development, as it has a direct effect on the population's health conditions, environmental preservation, including the achievement of international development targets. ${ }^{148}$ Nevertheless, Nigeria's current water law framework is devoid of detailed regulations. Although administrative structures such as the Federal Ministry of Water Resources exist, there is a lack of efficient personnel to carry out the tenets of water legislation. Weak databases regarding water remain a problem and the overall governmental attitude towards environmental and water issues seems to be lacking political will. The water resource sector also faces the challenge, among others, of unclear roles and responsibilities among the various levels of government, different ministries, departments and agencies at the federal and state levels. ${ }^{149}$ Existing legislation set out above fails to inspire litigation relating to enforcement of water rights similar to the Mazibuko case in South Africa, as the Constitution precludes the enforcement of a water right in Nigeria. Whilst Nigeria has likewise been an important venue in the fight for environmental justice, ${ }^{150}$ this venue has so far only expanded to the extractive sector ${ }^{151}$ and not to the water sector.

Key imperatives of the water reform in Nigeria are, inter alia, geared towards: ${ }^{152}$

harnessing the current and potential opportunities and addressing operational challenges within the water resources sector with a view to ascertaining the nature and level of investment required in the sector; and ensuring easy accessibility of supply of water to all Nigerians, including the poor and the most rural.

Nigeria needs 56 billion litres of water supply of potable water per day for domestic use only as well as enough water for industrial and agricultural use. ${ }^{153}$ The Nigerian government recognises the need to build commensurate capacity to cope with the level of demand in water and its infrastructure and that policy inconsistency in the sector at

147 Sections 1(1) and 2, Water Resources Act 1993.

148 Federal Ministry of Water Resources (2016: 1).

149 Ibid: 7

150 UNDP (2014: 19).

151 One expression of this has been the plight of local indigenous peoples in the Niger Delta, with increasing community claims of redress for toxic impacts and alleged rights abuses. The Ogoni are one among many indigenous communities in southeast Nigeria, rising to prominence in the environmental justice movement after a massive campaign against large oil multinationals in the Delta, under the umbrella of the Movement for the Survival of the Ogoni People (MOSOP). See UNDP (2014: 19).

152 Federal Ministry of Water Resources (2011: 8).

153 Ibid: 26. 
both federal and state government levels has overtime hampered the development of the water resources sector in the country. ${ }^{154}$ The attendant consequences have been the abandonment of laudable programmes halfway due to policy somersault ${ }^{155}$ or the frequent breakdown or deterioration of water plants due to lack of maintenance. ${ }^{156}$

Consequently, the Nigerian government set long-term goals, which seek to achieve $100 \%$ coverage in provision of potable water supply per day for domestic, industrial and agricultural uses by the year $2030 .{ }^{157}$ The rationale behind these proposed achievements is reflected in the revised National Water Resources Policy. Such includes, inter alia, that no ownership of water but only a right for environmental and basic human needs or an authorisation for its use; and management of water resources shall seek to harmonise human and environmental requirements so that the human use of water does not individually or cumulatively compromise the long-term sustainability of aquatic and associated ecosystems. ${ }^{158}$ The government also envisages the support of states to improve the capacity for water resource development, strengthening partnerships and collaboration with stakeholders to increase funding for the water resource sector in all states. ${ }^{159}$ Additionally, the National Water Resources Draft Policy 2016 has set out roles and responsibilities of key institutions managing water resources in Nigeria to avoid fragmentation and overlapping of roles. ${ }^{160}$

Whilst these future projections are laudable, this chapter argues that it is imperative for the Nigerian government to apply adaptive governance strategies to its water law reform. Existing water legislation fails to provide an effective basis for the achievement of water security and the absence of a water right in the Nigerian Constitution "serves" as hindrance to environmental justice. Whilst the use of environmental justice should be a means to ensure equity and accessibility to water in Nigeria, this appears to be a non-achievable concord when compared to South Africa, which provides the relevant impetus for environmental justice movements and the basis for adaptive governance in water legislation.

154 Ibid: 27.

155 Ibid.

156 Akali et al. (2014: 3).

157 Federal Ministry of Water Resources (2015 and 2016: 15).

158 Federal Ministry of Water Resources (2016: 12-13).

159 The government also recognises the need to create sustainable funding for the reform and promote private sector participation and collaboration. See Federal Ministry of Water Resources, (2011: 43) and Federal Ministry of Water Resources (2016: 29-31).

160 For an expansion of the roles of these key institutions, see Federal Ministry of Water Resources (2016: 32-40). 
Water is an important resource for human beings and the environment. Beyond viewing the resource as a paradigm of aid giving and water access, there must be a wider conceptualisation of water ${ }^{161}$ as a 'secure' resource in jurisdictions where issues of marginalisation were rampant. Given the magnitude of the resource and the international and national recognition of the right to water, it is clear that the achievement of water security is a key developmental goal for any nation. Whilst many versions of water security exist, it is left for governments at the national level to develop an allencompassing definition of what constitutes water security within their jurisdiction, bearing in mind the historical inequalities relating to accessibility and affordability of that resource. Nonetheless, increasing attention to water as a socio-ecological system, which requires adaptation to changing circumstances calls for adaptive governance in addressing water issues.

This chapter highlights the South African Constitution's forethought of including a right to water, which is a key driver to achieving water security, and the drawbacks within the Nigerian context stemming from the provisions of the 1999 Constitution. Whilst the full achievement of water security still remains an elusive paradigm in both jurisdictions, there appears to be an achievable concord between environmental justice and water security. Consequently, a key tool towards achieving this concord is for governments to have the political will to apply adaptive governance strategies to water law reform. The implementation of an adaptive governance approach to water security means that governments must exhibit a committed stand towards understanding the drivers of water security as the basis for informed decisions about water law reform and proposed investments for water infrastructure. Another implication requires governments' consciousness of the need for inclusive community/stakeholder participation in dialogues relating to water law reform.

The chapter emphasises the need to ensure water security in jurisdictions like South Africa and Nigeria where specific communities still experience water shortages. Both historical inequalities and extreme poverty hamper environmental justice where developmental policies, legislation and institutions should ensure the progressive realisation of water security for the benefit of present and future generations.

\section{References}

ACAPS / The Assessment Capacities Project Crisis Profile Nigeria (4-7-2016), at $<$ https://www.acaps.org/sites/acaps/files/products/files/160712_acaps_crisis_profile_northeast_nigeria_b.pdf $>$ (accessed 12-12-2017).

161 Allouche et al. (2011: 168). 
Adebowale, N (2017) “Over 180 million people lack drinking water in Nigeria, other countries facing conflicts - UNICEF" Premium Times (29-8-2017), at <https://www.premiumtimesng.com/regional/nnorth-east/241897-180-million-people-lack-drinking-water-nigeria-countries-facing-conflicts-unicef.html> (accessed 15-12-2017).

Agyeman, J, R Bullard \& B Evans (2002) "Exploring the nexus: bringing together sustainability, environmental justice and equity" 6(1) Space and Polity 70-90.

Akali, DM, OT Iorhemen, JA Otun \& MI Alfa (2014) "Provision of sustainable water supply system in Nigeria: a case study of Wannune-Benue State" 2(1) World Journal of Environmental Engineering 1-5.

Allan C, J Xia \& C Pahl-Wostl (2013) "Climate change and water security: challenges for adaptive water management" 5(6) Current Opinion on Environmental Sustainability 625-632.

Allouche, J, A Nicol \& A Walnycki (2014) "Global environmental justice and the right to water: the case of peri-urban Cochabamba and Delhi" 54 Geoforum 158-166.

Allouche, J, A Nicol \& L Mehta (2011) "Water securitization: towards the human securitization of water" 12(1) The Whitehead Journal of Diplomacy and International Relations 153-171.

Armitage D, F Berkes \& N Doubleday (2007) Collaboration, learning and multi-level governance: adaptive Co-management.

Backeberg, GR (2005) "Water institutional reforms in South Africa" 7 Water Policy 107-123.

Bond, P (2013) "Water rights, commons and advocacy narratives" 29(1) South African Journal of Human Rights 125-143.

Chikozho C, L Danga \& D Saruchera (2017) “Articulating the history and major departure points evident in post-apartheid South African national water policy and law" 100 Physics and Chemistry of the Earth 270-277.

Chiro, G Di (1996) "Nature as community: the convergence of environment and social justice" in W Cronon (ed.) Uncommon ground: rethinking the human place in nature 298-320.

Cook, C \& K Bakker (2012) "Water security: debating an emerging paradigm" 22 Global Environmental Change 94-102.

Cook, C \& K Bakker (2016) "Water security: critical analysis of emerging trends and definitions" in C Pahl-Wostl, A Bhaduri \& J Gupta (eds) Handbook on water security 19-37.

Cooney, R \& TF Lang (2007) "Taking uncertainty seriously: adaptive governance and international trade" 18 European Journal of International Law 523-551.

Couzens, E (2015) "Avoiding Mazibuko: water security and constitutional rights in southern African case law" 18(4) Potchefstroom Electronic Law Journal 1162-1186.

Daniels, R (2006) "Implementation of the right of access to sufficient water through privatization in South Africa” 15 Pennsylvania State Environmental Law Review 61-68.

Dietz, T, E Ostrom \& PC Stern (2003) "The struggle to govern the commons" 302(5662) Science 1907-1912.

DWAF / Department of Water Affairs (2013) National water resource strategy: water for an equitable and sustainable future $2^{\text {nd }} \mathrm{Ed}$.

DWAF / Department of Water Affairs and Forestry (1997) White paper on a national water policy.

Federal Ministry of Water Resources (2011) Executive summary of the Nigeria water sector roadmap, at <http://awdrop.org/wp-content/uploads/2017/01/water-roadmap.pdf $>$ (accessed 29-12-2017).

Federal Ministry of Water Resources (2015) Partnership for expanded water supply, sanitation \& hygiene (PEWASH) - programmed strategy (2016-2030).

Federal Ministry of Water Resources (2016) National water resources policy final draft. 
Folke, C, T Hahn, P Olsson \& J Norberg (2005) “Adaptive governance of socio-ecological systems" 30 Annual Review of Environment and Resources 441-473.

Foster, S \& A MacDonald (2014) "The water security dialogue: why it needs to be better informed about groundwater" 22(7) Hydrogeology Journal 1489-1492.

Garrick, D \& JW Hall (2014) "Water security and society: risks, metrics, and pathways" 39 Annual Review of Environment and Resources 611-639.

Global Water Partnership (2000) Towards water security: a framework for action.

Godden, L (2005) "Water law reform in Australia and South Africa: sustainability, efficiency and social justice" 17(2) Journal of Environmental Law 181-205.

Gowlland-Gualtieri, A (2007) South Africa's water law and policy framework - implications for the right to water IELRC Working Paper.

Grey, D \& CW Sadoff (2007) "Sink or swim? water security for growth and development" 9 Water Policy 547-548.

Gunderson, L (1999) "Resilience, flexibility and adaptive management - antidotes for spurious certitude?" 3(1) Conservation Ecology 7-17.

Hall, J \& E Borgomeo (2013) "Risk-based principles for defining and managing water security" Philosophical Transactions of the Royal Society A 371, 1-23.

Hardberger, A (2005-2006) "Life, liberty, and the pursuit of water: evaluating water as a human right and the duties and obligations it creates" 4(2) Northwestern Journal of International Human Rights 331-362.

Henderson, RH \& T Sundaresan (1982) “Cluster sampling to assess immunization coverage: a review of experience with a simplified sampling method" Bulletin of the World Health Organization, at $<$ http://www.ph.ucla.edu/epi/rapidsurveys/bulletinwho60(2)253_260_1982.pdf > (accessed 2012-2017).

Honkonen, T (2017) "Water security and climate change: the need for adaptive governance" 20 Potchefstroom Electronic Law Journal 1-26.

Hornstein, DT (2005) "Complexity theory, adaptation, and administrative law" 54 Duke Law Journal 929-933.

Humby, T \& M Grandbois (2010) "The human right to water in South Africa and the Mazibuko decisions" 51 Les Cahiers de Droit 521-540.

Ibrahim, SI (2012) "Water security and good governance in Niger State of Nigeria: challenge for sustainable development” 2(8) Transitional Journal of Science and Technology 68-78.

IUCN / International Union For Nature Conservation (2007) Human rights and the environment: overlapping issues.

Kasrils, R (Minister of Water Affairs and Forestry) (2003) "Foreword" in D Reed \& M Dewit (eds) Towards a just South Africa: the political economy of natural resource wealth.

Kaswan, A (2012) "Environmental justice and environmental law" 24(2) Fordham Environmental Law Review 149-179.

Keesen, AM \& HFMW Van Rijswick (2012) “Adaptation to climate change in european water law and policy" 8(3) Utrecht Law Review 38-50.

Kemerink, JS, R Ahlers \& P Van der Zwaag (2011) “The struggle for water at catchment level” Water SA 585-594.

Langford, M (2005) "The United Nations concept of water as a human right: a new paradigm for old problems?” 21(2) International Journal of Water Resources Development 273-282.

Larson, RB (2013) "The new right in water" 70(4) Washington \& Lee Law Review 2181-2267.

Larson, RB (2017) “Water security” 112(2) Northwestern University Law Review 139-200. 
MacKay, HM, KH Rogers \& DJ Roux (2003) "Implementing the South African water policy: holding the vision while exploring an uncharted mountain” 29(4) Water SA 353-358.

Magaziner, AL (2008) "The trickle-down effect: the Phiri water rights application and evaluating, understanding, and enforcing the South African constitutional right to water" 33 North Carolina Journal of International Law and Commercial Regulation 512-516.

Mehta L, F Marshall, S Movik, A Stirling, E Shah \& A Smith (2007) Liquid dynamics: challenges for sustainability in water and sanitation STEPS Working Paper.

Nnamuchi, O (2008) "Kleptocracy and its many faces: the challenges of justiciability of the right to health care in Nigeria" 52(1) Journal of African Law 1-42.

Obani, P \& J Gupta (2016) "Human security and access to water, sanitation, and hygiene: exploring the drivers and nexus" in C Pahl-Wostl, A Bhaduri, \& J Gupta (eds) Handbook on water security 201-214.

Oglethorpe, J (2002) Adaptive management: from theory to practice.

Onzivu, W (2013) "(Re) invigorating the health protection objective of the Basel Convention on Transboundary Movement of Hazardous Wastes and their Disposal” 33(4) Legal Studies 621-649.

Pachova, NI, M Nakayama \& L Jansky (2008) International water security domestic threats and opportunities.

Pahl-Wostl, C, M Palmer \& K Richards (2013) "Enhancing water security for the benefits of humans and nature - the role of governance" 5(6) Environmental Sustainability 676-684.

Peart, R \& K Govender (2001) "Natural resource policies for the new millennium" 8(1) South African Journal of Environmental Law and Policy 39-76.

Perkins, J (2003) "Partitioning water use in South Africa" in Australian Academy of Technological Sciences and Engineering Proceedings of the 2003 Invitation Symposium, Water the Australian Dilemma 148.

Pienaar, GJ \& E Van der Schyff (2007) "The reform of water rights in South Africa” 3(2) Law, Environment and Development Journal 181-194.

Postel, S (1999) Pillar of sand: Can the irrigation miracle last?

Punch (2017) "Drought conflict behind water scarcity in Nigeria, others - UNICEF" (22-3-2017), at $<$ https://punchng.com/drought-conflict-behind-water-scarcity-in-nigeria-others-unicef/> (accessed 18-12-2017).

Roithmayr, D (2010) "Lessons from Mazibuko: persistent inequality and the commons" 3(1) Constitutional Court Review 317-346.

Ruhl, JB (1997) "Thinking of environmental law as a complex adaptive system: how to clean up the environment by making a mess of environmental law" 34(4) Houston Law Review 933-1002.

Ruhl, JB (2009) "Laws complexity: a primer” 24(4) Georgia State University Law Review 885-911.

Schlosberg, D (2013) "Theorising environmental justice, the expanding sphere of a discourse" 22(1) Environmental Politics 1-48.

Scholz, JT \& B Stiftel (eds) (2005) Adaptive governance and water conflict: new institutions for collaborative planning.

Schreiner B, B Van Koppen \& N Mohapi (2004) "Washing away poverty: water, democracy and gendered poverty eradication" 28(3) South Africa Natural Resources Forum 171-178.

Soyapi, C \& T Honkonen (2017) “Water security” 20(1) Potchefstroom Electronic Law Journal: Special Edition 1-26.

Stein, R (2000) "South Africa's new democratic water legislation: national government's role as public trustee in dam building and management activities" 18(3) Colorado Journal of International Environmental Law \& Policy 284-295. 
Takacs, D (2016) "South Africa and the human right to water: equity, ecology and the public trust doctrine" 34(2) Berkeley Journal of International Law 55-108.

Tarlock, D (2008) "Water security, fear mitigation and international water law" 31(3) Hamline Law Review 703-728.

Tarlock, D \& P Wouters (2009) "Reframing the water security dialogue" 20 Journal of Water Law 53-60.

Tewari, D (2009) "A detailed analysis of evolution of water rights in South Africa: an account of three and a half centuries from 1652 AD to present" 35(5) Water $S A$ 693-710.

UKAID \& UNICEF (2017) Promising practices in WASH - some case studies of Nigeria, at $<\mathrm{https}$ ://www.unicef.org/nigeria/resources_11310.html $>$ (accessed 12-12-2017).

UN-Water (2013) UN-Water analytical brief water security and the global water agenda, at $<$ http://www.unwater.org/water_security_brief.html> (accessed 10-12-2017).

UNDP / United Nations Development Programme (2006) Beyond scarcity: power, poverty and the global water crisis.

UNDP / United Nations Development Programme (2014) Environmental justice - comparative experiences in legal empowerment, at $<\mathrm{http} / / / \mathrm{www}$. undp.org/content/dam/undp/library/Democratic\%20Governance/Access\%20to\%20Justice\%20and\%20Rule\%20of\%20Law/EnvironmentalJustice-Comparative-Experiences.pdf> (accessed 29-12-2017).

UNHRC / United Nations Human Rights Council (2011) Study on human rights and the environment UN Doc. A/HRC/19/34.

UNICEF / United Nations Children's Fund (2014) Impact evaluation of water, sanitation and hygiene (WASH) within the UNICEF country programme of cooperation, Government of Nigeria and UNICEF 2009-2013, at < https://www.unicef.org/nigeria/resources_11396.html> (accessed 19-122017).

United Nations News "UN united to make the right to water and sanitation legally binding", at $<$ http://www.ohchr.org/en/NewsEvents/Pages/Display-News.aspx?NewsID=10403\&LangID=E $>$ (accessed12-12-2017).

United Nations News (2010) "UN united to make the right to water and sanitation legally binding" at $<$ https://newsarchive.ohchr.org/EN/NewsEvents/Pages/DisplayNews.aspx?NewsID=10403\&LangID=E $>$ (accessed 12-12-2017).

Vanderwarker, A (2012) "Water and environmental justice" in J Christian-Smith, PH Gleick, H Cooley, L Allen, A Vanderwarker and KA Berry Twenty-First Century U.S. Water Policy, 53-89.

Wesson, M (2011) "Reasonableness in retreat? the judgement of the South African Constitutional Court in Mazibuko v City of Johannesburg" 11(2) Human Rights Law Review 390-405.

Willis, B, BS Geach, V Pillay, D Versfeld \& CM Shackleton (2000) "Review of policies and legislation influencing the sustainable use of South Africa's indigenous woodlands" 7(2) South African Journal of Environmental Law and Policy 171-201.

Woodhouse, P (2008) Water rights in South Africa: insights from legislative reform BWPI Working Paper No. 36.

Wouters, S, V Vinogradov \& BC Magsig (2009) "Water security, hydro solidarity, and international law: A river runs through it” 19 Yearbook of International Environmental Law 97-134.

Xia, JLZ, C Lu \& J Yu (2007) "towards better water security in north China” 21(1) Water Resources Management 233-247.

Zeitoun, M (2013) "Global environmental justice and international transboundary waters: an initial exploration" The Geographical Journal, at <http://dx.doi.org/10.1111/j.1475-4959.2012.00487> (accessed 29-12-2017). 
